\title{
GEOMATICS DOCUMENTATION TECHNIQUES AS MONITORING TOOLS FOR RURAL BUILT HERITAGE IN NABÓN (ECUADOR)
}

\author{
A. Collado ${ }^{1, *}$, V. Heras ${ }^{2}$, P. Rodas ${ }^{3}$, A. Delgado ${ }^{2}$, C. Carrión ${ }^{4}$, G. Mora-Navarro ${ }^{1}$, J.L. Lerma ${ }^{1}$
}

\author{
${ }^{1}$ Dept. of Cartographic Engineering, Geodesy and Photogrammetry, Photogrammetry and Laser Scanning Research Group (GIFLE), \\ Universitat Politècnica de València, 46022 Valencia, Spain - acolmur@ topo.upv.es, (joamona, jllerma)@cgf.upv.es \\ ${ }^{2}$ Facultad de Diseño, Arquitectura y Arte, Universidad del Azuay, Ave 24 de Mayo 7-77, Cuenca, Ecuador - \\ (vheras, adelgado)@uazuay.edu.ec \\ ${ }^{3}$ Instituto Nacional de Patrimonio Cultural (INPC), Ecuador - paula.rodas@ patrimoniocultural.gob.ec \\ ${ }^{4}$ Gobierno Autónomo Descentralizado de Nabón (GAD Nabón), Nabón, Azuay, Ecuador - cristina.carrion@ @abon.gob.ec
}

KEY WORDS: Arches, cultural documentation, RPAS close-range photogrammetry, international cooperation, augmented reality, heritage monitoring

\begin{abstract}
:
Since 2008, the Ecuadorian Constitution gave all the rights and responsibilities to the municipalities to preserve and enhance their cultural and natural heritage. Despite the heritage richness of Nabón, historically has been considered as a poor and under development territory of the province and the country. Nevertheless, for small and rural territories like Nabón in Azuay's Province (Ecuador), the resources intended for cultural conservation are usually scarce and/or limited, and consequently it reduces the potential development of appropriate measures and preventive conservation. Because of this, the present cooperation project between international institutions aims to reverse this situation generating an appropriate working methodology with the collaboration of architects and geomatics engineers. The latter experts have been developing their profession in the field of heritage in recent times generating the geometric documentation of heritage and enhancing it by disseminating and visualizing it through geoportals and the use of mobile applications. All this geometric documentation, altogether with historical and cultural heritage information available will make it possible to monitor the existing heritage in the site, inasmuch as until now no official monitoring instrument has been established in this Ecuadorian province.
\end{abstract}

\section{INTRODUCTION}

\subsection{Context}

Nabón or Nabun -in Quechua- as it was called during the Cañari era, was a wide territory populated by the Cañaris, one of the first human settlements that were present in the south of Ecuador (Figure 1).

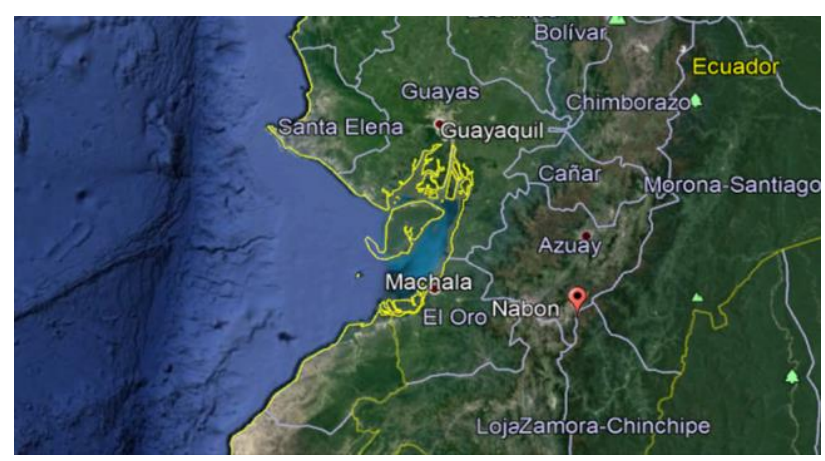

Figure 1. Location of Nabón in Azuay's Province and Ecuador (Source: Google Maps).

At the end of the 15th century, the Inca arrived and occupied this territory. From that period the language, social organization, agricultural technologies, and rituals exist until today. In the 16th century during the Spanish arrival and settlement, Nabón and its territory became the social property of the church and later they were owned by particular inhabitants. On July 7, 1987 Nabón became Canton of Azuay's Province (González-Muñoz, 2006).
Since that time, the economic activity in Nabón has been linked to agriculture, the textiles with the production of wool and cotton fabrics have been an important economic resource (GAD Cantón Nabón, 2014). In terms of culture, the people of Nabón are distinguished by their religiosity and devotion to the Virgen del Rosario, which is located in the main and old church of Nabón. Even if Nabón is a small town, it has an important architectural asset in the urban area. For all these reasons, on December 8, 2005 the urban area of Nabón was declared as National Cultural Heritage (Figure 2).

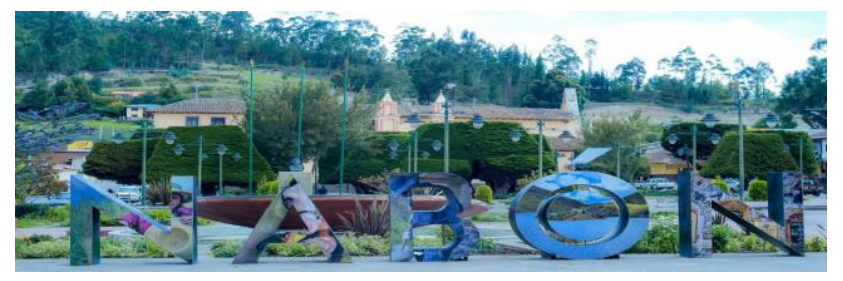

Figure 2. The main square of Nabón.

\subsection{Objectives}

Since 2008, the Ecuadorian Constitution gave all the rights and responsibility to the Municipalities to preserve their cultural and natural heritage. Nevertheless, for small territories like Nabón, the resources for cultural conservation are usually scarce and/or limited, and consequently, it reduces the potential development of appropriate measures and preventive conservation actions that are directly related to the integrated and holistic conservation approach. This approach starts from a preventive attitude towards conservation and is based on a long-term planned vision. 
Therefore it is based on condition assessments and periodic monitoring of risks as well as deterioration causes in order to facilitate early damage detection and minimum intervention. This process ensures, more than curative conservation, the integrity of heritage values, avoids a reactive pattern whereby the heritage fabric is lost and reduces costs for private owners in the long-term (Dann and Wood, 2004; Forster and Kayan, 2009). In practice, preventive conservation entails a threefold approach: (1) correct (re)-use and avoid the causes of damage, (2) early detection of the symptoms of damage by means of monitoring, (3) avoiding the further spread of damage and agents of deterioration through maintenance and necessary interventions (Van Balen, 2017).

The importance of this paradigm shift is paramount since different international organizations started implementing a pro-active approach towards monitoring and maintenance, aspects that are relevant in Nabón. In consequence, in 2019, the Municipality of Nabón looked for strategic partners that could support them in the development of management tools for heritage decision making and continuous monitoring. Therefore, the Universidad del Azuay (Ecuador), Universitat Politècnica de València (Spain), and the National Heritage Institute (Instituto Nacional de Patrimonio Cultural -INPC-) started an important collaboration program with the Municipality of Nabón.

The objective of the collaboration is to develop a sustainable management system that strengthens the empowerment of the rural community of Nabón, through the implementation of a management model for the documentation, dissemination, conservation, and monitoring of cultural and natural heritage assets. This management model will consist of a web geoportal where all the heritage information documented with geomatics techniques, architectural and archaeology means namely information provided by the INPC will be displayed and stored; and a mobile app that will allow society to actively participate in the monitoring of the documented elements.

\subsection{Case study: Church of Nabón}

Nabón is a canton in the province of Azuay located $69 \mathrm{~km}$ from the city of Cuenca, the capital province. One of its most important geographical characteristics is the dispersion of its territory, that have enabled the implementation of activities associated with the rural context, such as agriculture and cattle raising.

Nabón has a wide variety of cultural and natural heritage that makes it a unique and pioneering potential to achieve the objectives of this project. In this case and as a pilot project, we have focused on the parish church of Nabón to develop and expose the methodology devised and applied in the area.

The main church of Nabón is called "San Juan Bautista". It is located within the Historic Center. The property belongs to a vernacular typology that has been built in different periods through the history of Nabón. The morphology of the building corresponds to the model of a basilica, with two lateral naves and a central one of intense chromatic expression with interior arches. This church was built based on community work (mingas) and it represents a historical landmark of the place. It is located next to the main square of Nabón, a strategic location within the Cantón. The main square and its surroundings are configured as an important meeting place in Nabón, where commerce and local activities evidence daily life activities.
As it was mentioned before, the church was built at different stages, the first stage dates from the early nineteenth century, later an intervention was carried out by Aurelio Torres Alvarado and Juan José Cordero, approximately in 1925 (Terán, 1947). According to the photographic archive of Mr. Honorio Ochoa, a local art historian, in 1940 during the stage of the Priest Justo A. Torres, the central nave of the church was intervened, giving, as a result, a new building level (Figure 3).

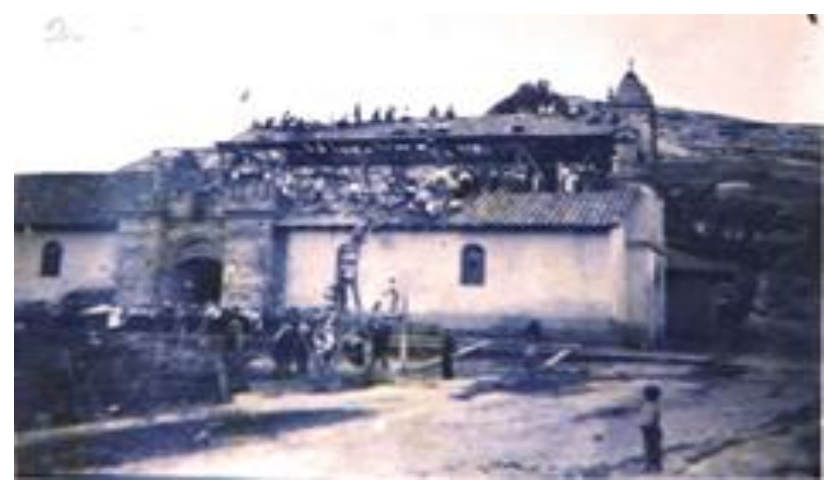

Figure 3. San Juan Bautista's church in Nabón (1940)

According to the mentioned photographic archive, in 1960, the church accesses were modified, particularly the south facade which was replaced by a modern-style concrete structure. In addition, the two existing towers of the main facade were extended; these transformations have been maintained until now (Figure 4).

Nevertheless, even if the church is considered the main building of Nabón, currently, its state of conservation is in bad condition. Different alterations such as moisture or biological actions are affecting this building. In this regard, the rehabilitation and enhancement of the main church is a fundamental and urgent project for the Municipality of Nabón.

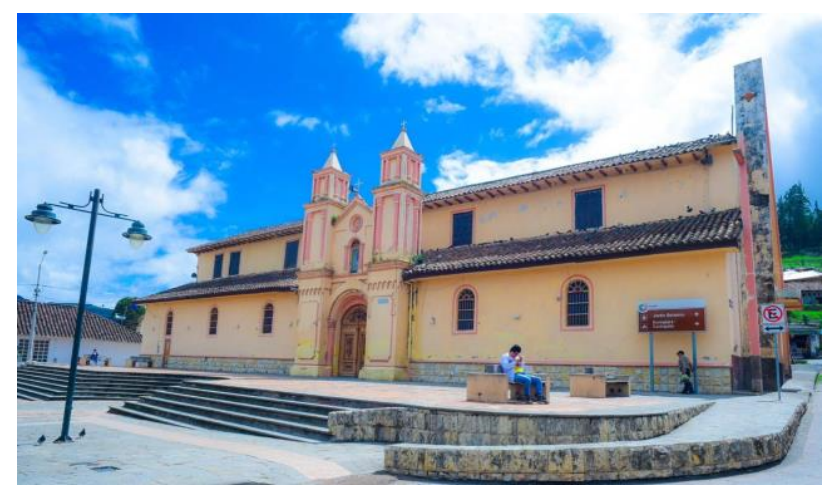

Figure 4. San Juan Bautista’s church in Nabón (2021)

Besides the physical recovery of the building, the conservation of traditional materials, building techniques and know-how are part of the main project targets. It is also important to mention that in all these activities the community and academic participation is sought as a driver for heritage identification and further appropriation.

In this context, the Municipality looked for strategic partners that could give support to the accomplishment of the described project's aims. 


\section{MATERIALS AND METHODS}

After knowing the context of Nabón, the objectives of the project and the case study chosen as a pilot test, the methodology followed to achieve the objectives will be presented.

The input data has a high load of geomatics and geoinformation techniques. Herein we will introduce the alphanumeric information available by the INPC on the chosen heritage element, as well as all the geometric documentation carried out by aerial photogrammetry with a drone and the graphic and metric products generated such as the 3D model that allows its geovisualization, either with a web viewer or with augmented reality. Also, the geoportal that has been implemented for the dissemination of this heritage element will be presented, as well as the monitoring tool created based on a mobile app.

The designed tool will contribute to the creation of participatory processes for monitoring the built cultural heritage -which in this particular case will focus on the Central Church of the canton of Nabón- involving not only professionals and experts, but also the general public. In this way, through the implementation of the computer tool and the mobile app, reports could be generated on the state of conservation of the church, based on the information entered by anyone who identifies damage to the building.

\subsection{INPC Inventory File}

The Ecuadorian Cultural Heritage Information System (SIPCE), is the official heritage information system used in Ecuador according to current national legislation. Article 39 of the "Ley Orgánica de Cultura del Ecuador" (Law of Culture in Ecuador), establishes the SIPCE as the main management and information tool of the Ecuadorian cultural heritage, and is articulated to integrate the comprehensive cultural information system of Ecuador.

SIPCE's management is under the responsibility of the INPC, and it is executed according to the technical regulations for the collection, classification, incorporation and dissemination of the information inherent to the inventory of assets of patrimonial interest, both material and immaterial. Currently, the SIPCE has information on approximately 170.000 cultural assets in Ecuador.

The documentation of these cultural properties is gathered through specific files (buildings, sites, landscape, inmaterial heritage, etc.). In addition, these records are structured in a relational database, therefore, information related to the geographic location of a particular asset, territorial statistics, and a general description is possible to be consulted in the INPC webpage.

In relation to the properties files, the main data is organized into different items (Table 1).

As it can be seen in Table 1, the file is mainly composed of items related to the alphanumeric documentation and description of the heritage building, features that allow a heritage value assessment of the property becoming a tool for identification and awareness as part of the national cultural heritage inventory.

\begin{tabular}{|c|}
\hline Identification data \\
\hline Location data \\
\hline Year of construction \\
\hline Lypology and building uses \\
\hline State of conservation \\
\hline Photographies of the building \\
\hline Description of the building \\
\hline Main volumetric description of the building \\
\hline Risks: natural and anthropogenic \\
\hline $\begin{array}{c}\text { Physical identification of the property: } \\
\text { description of materiality and pathologies }\end{array}$ \\
\hline Description of possible interventions \\
\hline Valuable elements (characteristics) \\
\hline Planimetric information of the property \\
\hline Additional photographs \\
\hline Required interventions \\
\hline General remarks \\
\hline Heritage assessment (Baremo scale) \\
\hline Control data \\
\hline Associated record sheets: historic inventories \\
\hline Photographic annexes \\
\hline
\end{tabular}

Table 1. SIPCE's items of the heritage building file

Specifically, for the church of Nabón, a cultural heritage building inventory file was implemented (Figure 5).

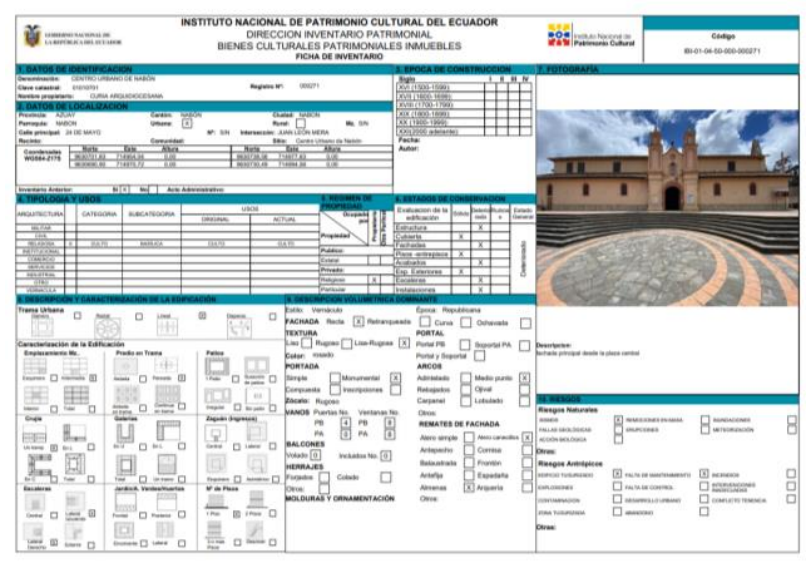

Figure 5. Nabón’s church inventory file

\subsection{Geometric Documentation}

In the $21^{\text {st }}$ century and since the end of the $20^{\text {th }}$ century, the conservation, preservation, and enhancement of heritage have taken an important relevance, producing a boom in the interest of society in all cultural heritage, as well as professionals who are dedicated to it.

The enhancement of heritage through the geometric documentation of heritage is one of the areas in which the geomatics engineer has been developing his profession in recent times. This is due to his great experience and competence in the techniques of photogrammetry, modelling, mapping and 3D geovisualization, among others. 
That is why, in the following sections we can find explicitly the whole process of heritage documentation carried out from data collection with a drone for the realization by means of aerial photogrammetry, as well as all the pre-processing of data from the captured images to obtain a dense point cloud, modelling and texturing of the point cloud and its visualization in a web viewer, last but not least, the augmented reality app developed for dissemination tasks.

2.2.1 Aerial Photogrammetry: As antecedent before the 3D modelling of the church, an ortophotography of the urban sector of Nabón was made with a resolution of $3 \mathrm{~cm} / \mathrm{px}$. It was spatially corrected by 10 GCPs established by GNSS techniques and also it was used to scale the model afterwards. For the photogrammetric survey of the parish church in the central part of the cantonal capital of Nabón, an RPAS (Remotely Piloted Aircraft System) or drone was used with a planned flight, but not automated, that is, the photographic coverage was done manually by the pilot of the drone. The drone used was the DJI Phantom 4 Pro 1st generation (Table 2) and in addition, using the DJI PRO 4 mobile application, the device was configured to capture images every $2 \mathrm{~s}$ along the entire planned route and without modifying the focal length of the camera $(8.8 \mathrm{~mm})$.

Recall, that for the optimal realization of the photographic coverage for photogrammetry it is necessary to follow the $3 \times 3$ rules adopted by CIPA (Waldhäusl, Ogleby, Lerma, Georgopoulos, 2013).

\begin{tabular}{|c|c|}
\hline Aircraft & DJI Phantom 4 Pro $1^{\text {st }} \mathrm{g}$. \\
\hline $\begin{array}{c}\text { Weight (Battery \& Propellers } \\
\text { Included) }\end{array}$ & $1388 \mathrm{~g}$ \\
\hline Max Wind Speed Resistance & $10 \mathrm{~m} / \mathrm{s}$ \\
\hline Max Flight Time & Approx. 30 minutes \\
\hline Operating Temperature Range & $32^{\circ}$ to $104^{\circ} \mathrm{F}\left(0^{\circ}\right.$ to $40^{\circ} \mathrm{C}$ ) \\
\hline Satellite Positioning Systems & GPS/GLONASS \\
\hline & Vertical: \\
$\pm 0.1 \mathrm{~m}$ (with Vision Positioning) \\
$\pm 0.5 \mathrm{~m}$ (with GPS Positioning) \\
$\begin{array}{c}\text { Horizontal: } \\
\text { Hover Accuracy Range }\end{array}$ & $\begin{array}{c} \pm 0.3 \mathrm{~m} \text { (with Vision Positioning) } \\
\pm 1.5 \mathrm{~m} \text { (with GPS Positioning) }\end{array}$ \\
\hline Aircraft Camera & $\begin{array}{c}\text { ', CMOS } \\
\text { Effective pixels: } 20 \mathrm{M}\end{array}$ \\
\hline Sensor & $\begin{array}{c}\text { FOV } 84^{\circ} 8.8 \mathrm{~mm} / 24 \mathrm{~mm}(35 \\
\text { mm format equivalent) } \mathrm{f} / 2.8- \\
\text { f/11 auto focus at } 1 \mathrm{~m}-\infty\end{array}$ \\
\hline Lens & \\
\hline &
\end{tabular}

Table 2. RPAS and camera characteristics

The data acquisition was performed following 3 different flight plans (Figure 6). First, as is essential in any architectural documentation work, a zenithal flight was performed by raising the drone above the building and placing the RPAS camera completely perpendicular for optimal data collection, especially of the entire roof. In the following flight plan, the drone was positioned at the height of the second story and the camera was tilted down about 30 degrees, taking convergent photographs following a horizontal trajectory, parallel to the facade, capturing both the entire facade of the church and part of the roof already photographed. Finally, the third flight plan consisted of a flight with the camera at a slightly small angle upwards and at a height of half of the ground floor following, as in the previous flight plan, a horizontal trajectory parallel to the building.

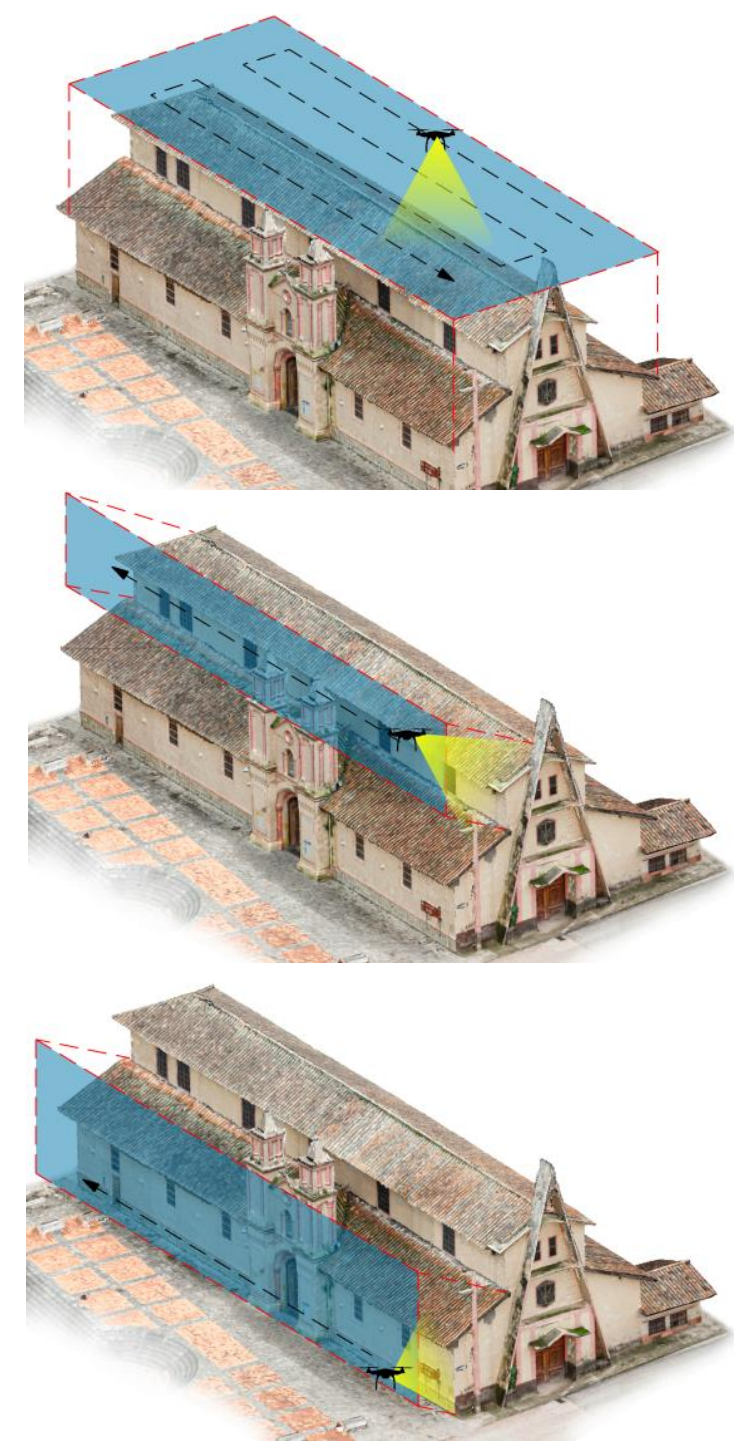

Figure 6. Flight plans with RPAS

The result of this photographic coverage yielded 472 photographs. Next, we will explain the process of obtaining this point cloud from the photographs taken with the Structure from Motion (SfM) photogrammetric technique, which allows the relative photogrammetric orientation.

This process will be carried out with Agisoft Photoscan software, in which the relative orientation is known as alignment of photographs, that is, the internal and external orientation of the camera is determined through the selfcalibration bundle adjustment of the photographs, as well as the search for homologous points to obtain the 3D point cloud. The process followed is common in SfM-based software.

For the alignment of photographs, the software has two parameters to take into consideration: Key Point Limit, default 40.000 , which is the maximum number of entities that the program will automatically extract from each photograph; and Tie Point Limit, default 4.000, which is the maximum number of homologous points that will be used for the matching process. The result is a sparse point cloud (Figure 7). The same figure also shows the layout of the real photographic acquisition. 


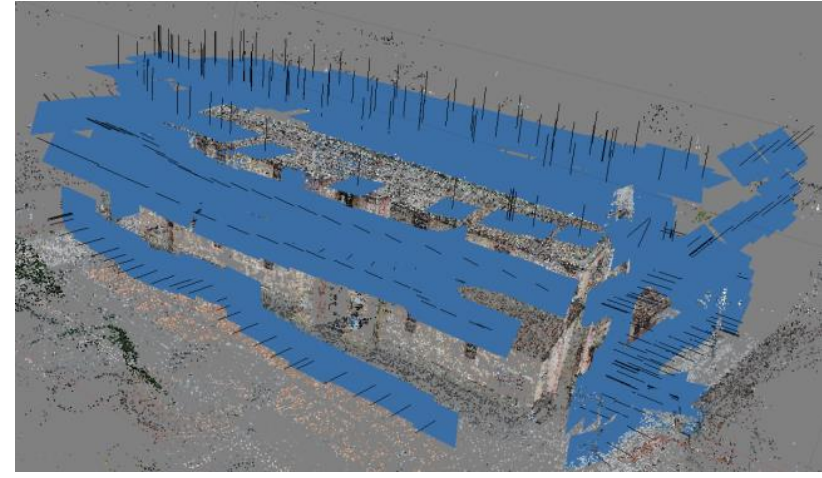

Figure 7. Nabón’s church sparse point cloud

At this point, it is advisable to take a look at the reports that the software generates, to know if the process is accurate and acceptable. More than 328 thousand homologous points have been found in the 472 oriented photos in about 45 minutes it has taken to perform the task. In addition, the reprojection error we have obtained was 0.7 pixel error, adequate for the case we are dealing with. From here, we can now create the dense 3D point cloud, in our case of high quality (Figure 8) that has taken about 2 days to process for the nearly 150 million points obtained. The computer used for processing was an MSI GP75 Leopard 9SD with Intel(R) Core(TM) i7-9750H CPU, 1TB SSD storage and all under a powerful NVIDIA GeForce(R) graphics card.

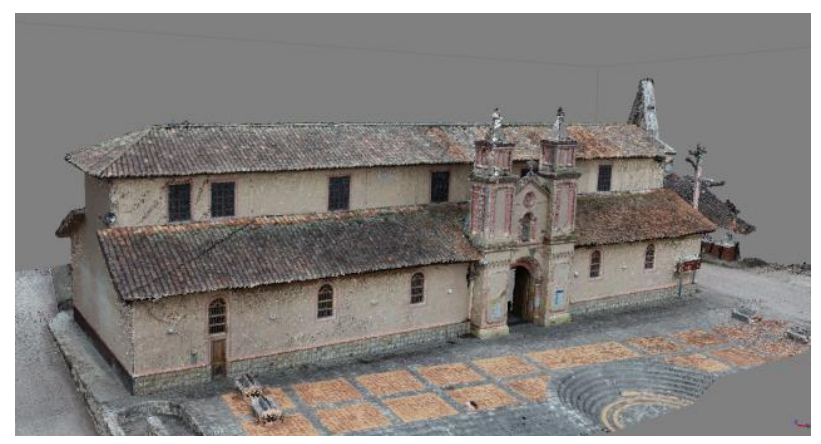

Figure 8. Nabón's church dense point cloud

2.2.2 3D Modeling: The objective at the present time is to transform the dense point cloud to a 3D model clean of noise and free of holes, i.e., a high-quality 3D model. Regarding the software used, the 3D model was created with Agisoft Photoscan (Figure 9).

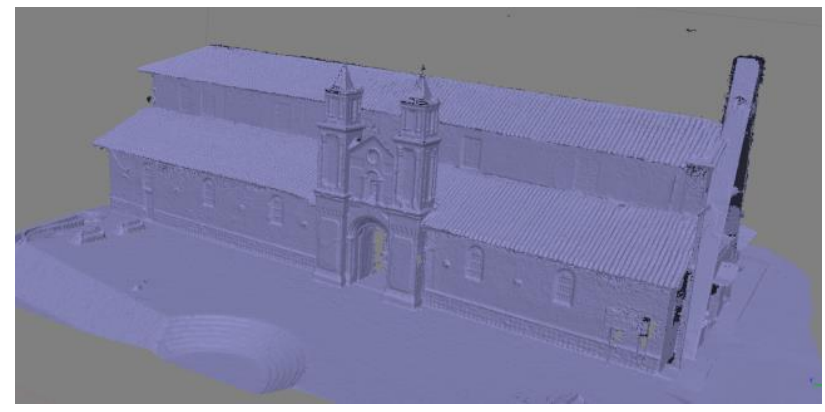

Figure 9. Nabón's church 3D model
Finally, when the 3D model is polished and free of holes, it has been textured in a photorealistic way (Figure 10), again in Agisoft Photoscan, with the photographs that were used for its creation. In the future, we are also planning to take hyperspectral and thermographic imagery since these imagery are very useful for the detection and localization of alterations in the building (Lerma, 2001; Sidiropoulou-Velidou, Georgopoulos and Lerma, 2012).

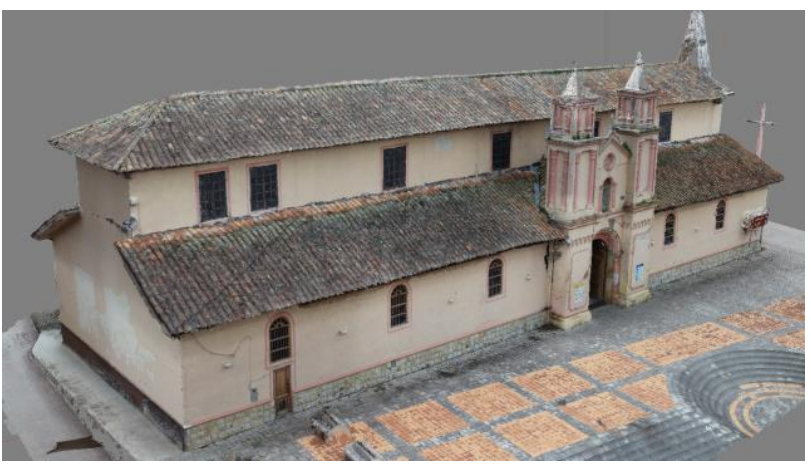

Figure 10. Nabón's church textured 3D model

With the 3D model already generated, it is a good moment to visualize it in a web viewer that allows society to contemplate and visualize it.

2.2.3 Geovisualisation and AR: The $3 \mathrm{D}$ model has been introduced in a web viewer that allows users to access instantly and online the visualization of the 3D model. This web viewer is currently in its final stage of development.

The web viewer has been generated with the 3DHOP (3D Heritage Online Presenter) tool, which is an open-source framework for the creation of interactive web presentations of high-resolution 3D models, oriented to the field of cultural heritage. The target audience for 3DHOP ranges from museum curators with some IT experience to experienced web designers who wish to incorporate $3 \mathrm{D}$ content into their creations, from students in the $\mathrm{CH}$ field to small companies developing web applications for museums and $\mathrm{CH}$ institutions (Potenziani, Callieri, Dellepiane, Corsini, Ponchio, Scopigno, 2015).

Moreover, geovisualization is not only about displaying the 3D model in a web viewer, but also encompasses augmented reality (AR) and 3D printing. In order to develop the augmented reality app of the church, the final 3D model and the texture of the object generated in a minimum quality of 8192 pixels is needed. Both in web viewers and any other computer application, a 3D model not too heavy will be needed, since lightness and speed are required for its uploading to the server or its $A R$ visualization through mobile devices.

Consequently, it has been seen appropriate to decimate the $3 \mathrm{D}$ mesh of the object in order to reduce its size or weight to optimize its visualization on mobile devices, thus having an object with 200.000 faces and 172.241 vertices which is much more optimal for visualization issues.

Once the reduced object is obtained, with the help of Adobe Dimension software the object is opened, the generated texture is placed as image filler with high quality, and it is exported in a USDZ file which can be viewed on any mobile device with an application for this purpose (Figure 11). 


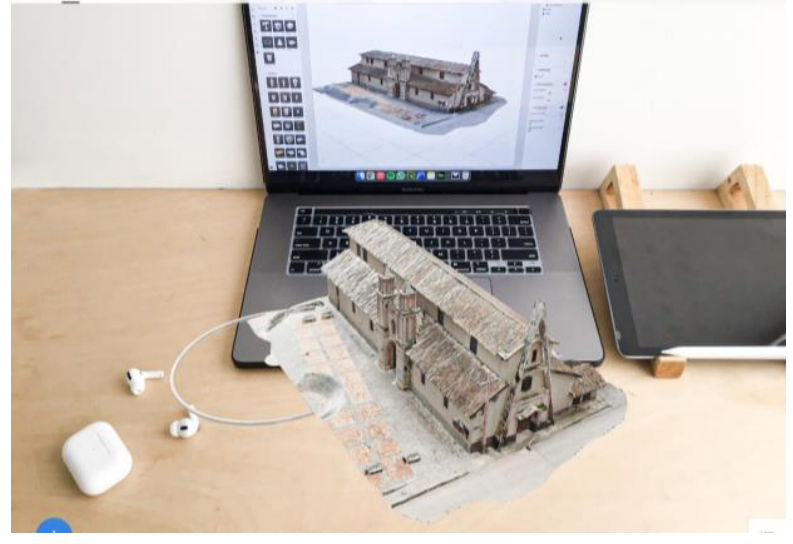

Figure 11. Nabón's church in augmented reality (AR)

In addition, it is planned to 3D print the obtained model of the church so that the parish priest, the town council and the inhabitants of Nabón can see the recreation of their church in miniature.

\subsection{Dissemination: Geoportal}

Geoportals are used in a wide range of fields, since they are software systems able to provide access to diverse information resources to different users, granted with different attributes. (Yamashkin et al., 2019) reported a list of functional and qualitative requirements when designing geoportal solutions, ensuring the sustainable development of the global society: availability of cartographic layout, ensuring combined thematic mapping overlapping, the existence of right navigation tools for moving across the geospatial data, access to the spatial object attributes, and the chance to reach complementary information from other multimedia sources.

In this scenario, after exploring the existing heritage systems, the Arches heritage inventory and management system (Myers, Dalgity, Avramides, 2016) has been choosing as one the best existing system for the development of the present project focused on the territory of Nabón (Lerma, Heras, MoraNavarro, Rodas, Matute, 2020) and specifically on its central parish church.

This geoportal is currently being designed and implemented (Figure 12) as a collaborative work between these institutions and taking into account the needs and reality of the town of Nabón.

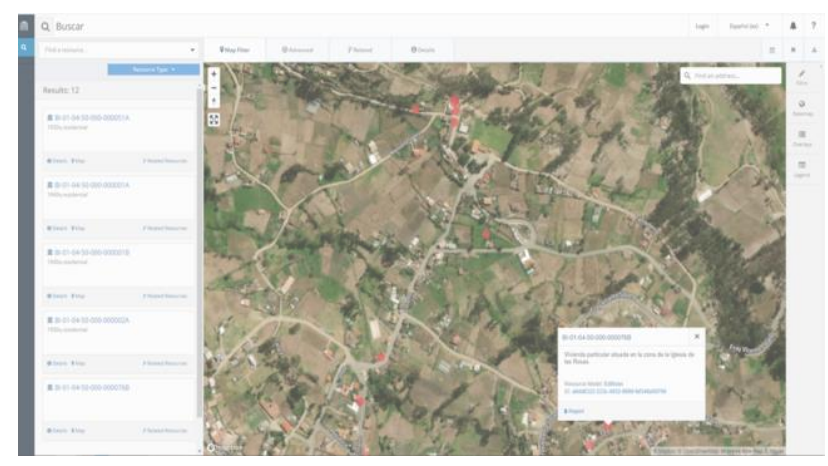

Figure 12. Nabón's heritage geoportal
As shown in (Collado, Mora-Navarro, Rodas, Heras, Lerma, 2021), it is necessary to know in advance and with precision the data model or models that will be required in the created geoportal because Arches and its database system follow ACID (atomicity, consistency, isolation and duration) as a persistence assurance mechanism.

Also, in terms of the data model, correspondence is currently being sought between the INPC SIPSE fields, as detailed above, and the ontology embedded in Arches complying with ISO 21127:2014 for the exchange of cultural heritage information.

We expect the geoportal to be visual and useful, containing different background base layers including one with orthophotography of the cantonal center made by ourselves, as well as the possibility of specific queries by filters and of all the geometric documentation generated.

\subsection{Monitoring Tool}

The conservation of cultural heritage is a process that requires multidisciplinary work, involving different areas of knowledge. In this sense, this research takes the statement of (Querol, 2010), that indicates "you cannot protect what is unknown".

Therefore, acquiring knowledge is the starting point of all management activity related to cultural heritage, in this context, the documentation process becomes a fundamental stage for conservation. In addition, heritage documentation is based on the collection, production, systematization, and analysis of the information of the cultural assets. With the purpose of accomplishing this activity, the involvement of different disciplines is important in order to achieve a holistic approach. Various methodologies, techniques and strategies allow the comprehension of the heritage asset not only within its physical space, but also in its social and cultural context, thus helping to understand the relationship between the human being and the territory (Mondéjar-Fernández, Fernández-Cacho, Soro-Cañas, 2017).

As it was previously described, in Ecuador there is an inventory system to document different types of heritage. However, until now an official monitoring tool has not been established. In this scenario, the current research took as a base the inventory file and starting from the risks set up a few elements that need to be monitored in time. The table below illustrates one of the project contributions in terms of heritage monitoring (Table 3 ).

\begin{tabular}{|c|c|c|c|}
\hline Risk & State & Data to monitor & $\begin{array}{l}\text { Specific } \\
\text { elements }\end{array}$ \\
\hline Biological action & $\sqrt{ }$ & $\begin{array}{c}\text { State of conservation } \\
\text { Main volumetric } \\
\text { description of the } \\
\text { building } \\
\text { Materials and pathologies }\end{array}$ & $\begin{array}{c}\text { Facade, interior } \\
\text { spaces, exterior } \\
\text { spaces. }\end{array}$ \\
\hline $\begin{array}{l}\text { Inadequate } \\
\text { interventions }\end{array}$ & $\sqrt{ }$ & $\begin{array}{l}\text { State of conservation } \\
\text { Description of the } \\
\text { building } \\
\text { Main volumetric } \\
\text { description of the } \\
\text { building } \\
\text { Materials and pathologies }\end{array}$ & $\begin{array}{l}\text { Structure, Roof } \\
\text { structure, } \\
\text { Facade, Interior } \\
\text { spaces, } \\
\text { Staircases, } \\
\text { Installations }\end{array}$ \\
\hline
\end{tabular}

Table 3. Items in terms of heritage monitoring 
As with the geoportal, we are currently working collaboratively to launch a mobile app that, with the help of Arches Collector, will enable a simple and intuitive application to be installed on the smartphone of each citizen (Figure 13). In this way, the citizen will be able to send to the city council, the final manager of the geoportal and the associated app, the imperfections observed in his own house or heritage elements of his community through photographs and the fields selected for the correct and appropriate monitoring.

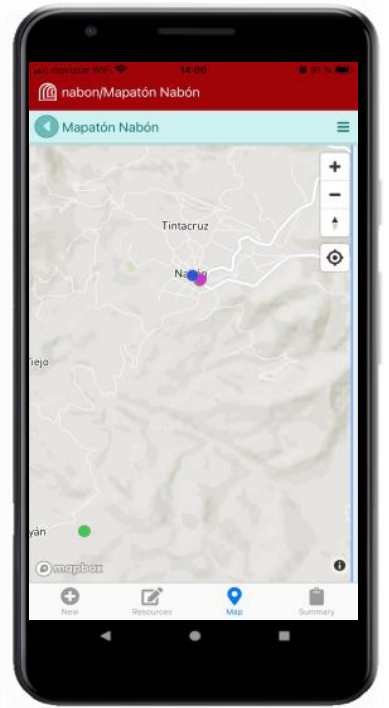

Figure 13. Monitoring App

In the case study, the church, it has been possible to check and start monitoring the pathologies suffered in its building, such as a large hole in the roof and the large amount of moisture and detachment of existing material on the facades. Thanks to this documentation and monitoring work, the municipality has already undertaken institutional actions to obtain funds for the rehabilitation of the church.

\section{RESULTS AND DISCUSSION}

Heritage assets documented and lately visualized in a 3D digital model create new possibilities - but also challenges -in their way of using but also analyzing the generated data (HudsonSmith, Evans, 2003).

Based on the Principles for the Analysis, Conservation and Structural Restoration of Architectural Heritage (ICOMOS, 2003), the preventive conservation approach entails a neverending loop that consists of four phases: analysis, diagnosis, therapy and control. The different phases correspond respectively to the search for significant data and information, individualization of the causes of damage and decay, choice of the remedial measures and control of efficient interventions. Therefore, preventive conservation consists of 4 steps that will use, produce and output new information.

The researchers identified that such an approach entails the systematic and continuous collecting and analysis of information about the diversity of the historic urban environment, to identify both values and risk and to provide responsible stakeholders with adequate information to make the right decisions at the right time in order to appropriately balance between a value-centred approach, minimum intervention and risk management of this resource.
Because of the obvious complexity, this approach demands a conceptual planning framework that should be supported by management tools such as monitoring systems and multi-criteria decision-making tools.

The photogrammetry as a documentation tool allows a quick and precise location of damages or existing problems in the building (Figure 14) such as a large hole in the roof and the large amount of moisture and detachment of existing material on the facades. Moreover, the continuous monitoring of structures in rural areas can be supported by these documentation tools but also by structuring the data for further adequate analysis.
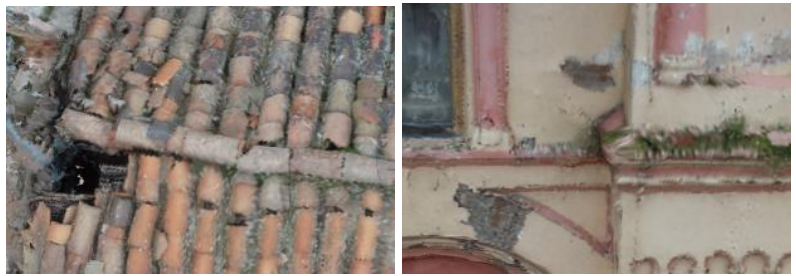

Figure 14. Damages in the church of Nabón

Therefore, the gathered data is not only for visual aims but mainly it can be part of periodic monitoring (Grosse, 2008). In this context and from the obtained results, the monitoring system is conceived as a tool to support decision making for intervention and maintenance planning, beyond the mere purpose of inventorying.

The proposed monitoring system has to deal with two essential aspects: 1) Heritage values as the features to be monitored; and, 2) A wide range of information, dealing with heritage objects documented with high geometrical and semantic precision.

We are therefore satisfied with the progress of this project and look forward to continuing to implement it so that it becomes fully operational.

\section{CONCLUSIONS}

The San Juan Baustista's church in Nabón, illustrates the potentials of relating ICT tools and heritage monitoring requirements. The use of photogrammetry as the main documentation tool for monitoring purposes has a high potential and is adequate for preventive conservation practices in rural areas. In addition, the obtained 3D model provides robust and up-to-date information on the state of conservation of the building. The research reveals some existing and future problems of the church which demonstrates the potential of photogrammetry not only as a documentation tool but also as a valuable input for monitoring purposes, fully integrated into a web based geoportal.

The described research is in progress. The design and implementation of the geoportal based on preventive conservation and monitoring activities also have demonstrated to us that there are still a number of challenges to be overcome in order to elaborate a fully-fledged preventive conservation tool. 


\section{ACKNOWLEDGEMENTS}

The authors acknowledge the support by the Centro de Cooperación al Desarrollo, Universitat Politècnica de València (Research Programmes ADSIDEO-COOPERACIÓN 2019 and MERIDIES-COOPERACIÓN 2020).

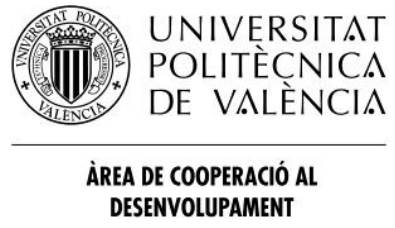

\section{REFERENCES}

Collado, A., Mora-Navarro, G., Rodas, P., Heras, V., Lerma, J.L., 2020. Cantón Nabón cultural heritage geoportal implementation: first steps. Proceedings of the 9th ARQUEOLÓGICA 2.0 \& $3 r d$ GEORES.

http://ocs.editorial.upv.es/index.php/arqueologica20/arqueologic a9/paper/viewFile/12179/6108

Dann, N., Wood, S., 2004. Tensions and omissions in maintenance management advice for historic buildings. Structural Survey, Vol. 22 No. 3, pp. 138-147. doi.org/10.1108/02630800410549035

Forster, A. M., Kayan, B., 2009. Maintenance for historic buildings: A current perspective. Structural Survey, 27(3), 210229. doi.org/10.1108/02630800910971347

GAD Cantón Nabón, 2014. Plan de Ordenamiento Territorial del Cantón Nabón. http://www.nabon.gob.ec/download/16421/

González-Muñoz, S., 2006. Experiencia de la gestión participativa en el Cantón Nabón. Final work of the Diploma in Sectional Government Management at the Universidad del Azuay. http://dspace.uazuay.edu.ec/handle/datos/2738

Grosse, C.U., Giovanni, P., Simon, S., Krüger, M., Troi, A., Colla, C., Rajčić, V., Lukomski, M., 2008. Recent Advances in Smart Monitoring of Historic Structures. In Proceedings 8th European Conference on Research for Protection, Conservation and Enhancement of Cultural Heritage (CHRESP).

Hudson-Smith, A., Evans, S., 2003. Virtual cities: from CAD to 3D GIS. Advanced spatial analysis: the CASA book of GIS. ESRI Press, Redlands, US, pp. 41-60.

ICOMOS, 2003. Principios para el análisis, conservación y restauración de las estructuras del patrimonio arquitectónico.

Lerma, J. L., 2001. Multiband versus multispectral supervised classification of architectural images. The photogrammetric record, 17(97), pp. 89-101. doi.org/10.1111/0031-868X.00169

Lerma, J.L., Heras, V., Mora-Navarro, G., Rodas, P., Matute, F., 2020. Geoportal proposal for the inventory of cultural heritage in Nabón (Ecuador). The International Archives of the Photogrammetry, Remote Sensing and Spatial Information Sciences, XLIII-B2-2020, 1415-1418. doi.org/10.5194/isprsarchives-XLIII-B2-2020-1415-2020
Mondéjar-Fernández, P., Fernández-Cacho, S., Soro-Cañas, S., 2017. Documentación del patrimonio inmueble. Introducción a la documentación del patrimonio cultural. (págs. 90-30). $\mathrm{PH}$ Cuadernos, 30. Instituto Andaluz del Patrimonio Histórico, Andalucía.

Myers, D., Dalgity, A., Avramides, I., 2016. The Arches heritage inventory and management system: a platform for the heritage field. Journal of Cultural Heritage Management and Sustainable Development, 6(2), 213-224. doi.org/10.1108/JCHMSD-02-2016-0010

Potenziani, M., Callieri, M., Dellepiane, M., Corsini, M., Ponchio, F., Scopigno, R., 2015. 3DHOP: 3D Heritage Online Presenter. Computers \& Graphics, Volume 52, 2015, Pages 129-141. doi.org/10.1016/j.cag.2015.07.001

Querol, M., 2010. Manual de Gestión del Patrimonio Cultural. Ediciones Akal S.A., Madrid.

Sidiropoulou-Velidou, D., Georgopoulos, A., Lerma, J.L., 2012. Exploitation of thermal imagery for the detection of pathologies in monuments. In Euro-Mediterranean Conference (pp. 97108). Springer, Berlin, Heidelberg. doi.org/10.1007/978-3-642-34234-9_10

Terán, C., 1947. Índice histórico de la Diócesis de Cuenca. Editorial Católica, Cuenca.

Van Balen, K., 2017. Challenges that Preventive Conservation poses to the Cultural Heritage documentation field. ISPRS International Archives of the Photogrammetry, Remote Sensing and Spatial Information Sciences. XLII-2/W5. 713-717. doi.org/10.5194/isprs-archives-XLII-2-W5-713-2017

Waldhäusl, P., Ogleby, C. L., Lerma, J. L., Georgopoulos, A., 2013. 3 x 3 rules for simple photogrammetric documentation of architecture. https://www.cipaheritagedocumentation.org/wpcontent/uploads/2017/02/CIPA_3x3_rules_20131018.pdf

Yamashkin, S.A., Radovanović, M.M., Yamashkin, A.A., Barmin, A.N., Zanozin, V.V, Petrović, M.D., 2019. Problems of designing geoportal interfaces. GeoJournal of Tourism and Geosites, 24(1), 88-101. doi.org/10.30892/gtg.24108-345 